\title{
FOOD SECURITY TO THE PEOPLE IN THE STATE OF GOA THROUGH PUBLIC DISTRIBUTION SYSTEM AMIDST COVID-19 PANDEMIC: AN EMPIRICAL STUDY
}

\author{
ANTHONY SATHISH ${ }^{1} \&$ NARENDRA B. GAONKAR ${ }^{2}$ \\ ${ }^{1}$ Associate Professor in Commerce, H.O.D. PG Department of Commerce and Research, Govt. College of Arts, \\ Scienece and Commerce, Quepem, Goa, India \\ ${ }^{2}$ Assistant Professor in Commerce, Department of Commerce UG, M. E. S. College of Arts \& Commerce, \\ Zuarinagar, Goa, India
}

\begin{abstract}
The outbreak of COVID-19 has grappled the entire globe with nobody as an exception. The threat looms over as the countries across the world are focusing on containment of the virus and simultaneously taking measures to save the economy. One of the major challenges is to ensure food security to people against the demon-COVID-19. India in its response to COVID-19 has taken series of measures. This paper focuses on the measures taken by government authorities to ensure food security through supply of essential commodities to people of the State of Goa. The data is collected from beneficiaries of Public Distribution System, the Fair Price Shop owners and the Department of Civil Supplies, Government of Goa. The response from beneficiaries is analyzed through factor analysis. The prominent problems faced by beneficiaries in accessing food grains at the Fair Price Shops include inadequacy of food grains, lack of adequate supervision, transport, poor service and safety issues. Subsequently, the prominent factors derived out of factor analysis are regressed on the unwillingness of the beneficiaries to visit the fair price shop. The challenges faced by Fair Price Shop owners in distribution of food grains to eligible beneficiaries are also studied. The actions taken by Department of Civil Supplies, Government of Goa to combat COVID-19 by ensuring the supply of essential commodities to beneficiaries are also highlighted in the study.
\end{abstract}

KEYWORDS: Public Distribution System, Essential Commodities, Food Security, Beneficiary, Fair Price Shop

Received: Jun 01, 2020; Accepted: Jun 20, 2020; Published: Jun 30, 2020; Paper Id.: IJMPERDJUN2020141

\section{INTRODUCTION}

Throughout the course of history, different pandemics have destroyed lives and have caused damage to property. The viruses have created havoc to the existence of humanity all around the globe. The present crisis of COVID-19 is not different. The lives are lost, economies have collapsed and entire world is devastated. In the unprecedented times such as these, it is of prime importance that the people in the country are assured of health, safety and food security to avoid the panic. Government of India has done its best to minimise the impact of virus. With respect to food security to people of India, the existing National Food Security Act 2013 is further supplemented with Pradhan Mantri Garib Kalyan Anna Yojana (PM-GKAY) to distribute food grains to people in India. The present study attempts to examine the measures taken to combat COVID-19 with special reference to the State of Goa.

\section{LITERATURE SURVEY}

The literature survey of prior studies is undertaken to understand the work studied by earlier researchers in the area 
of food security and pandemics.

Sivastav N., Dubey A. (2001) in their study titled 'How and Why the access to Public Distribution System does not enhance the food security among the people of North East India - An Inter State Analysis' concludes that the PDS is widely accessible to the households in the North-eastern Region of India. However, it is the lack of purchasing power that comes in the way of ensuring food security in the region. The authors further stresses on creation of job opportunities which would in turn improve food security situation.

Amrutha D., Rathi D. (2015), in the study on 'Role and Effectiveness of Public Distribution System in India' studied agricultural productivity and the food security through Public Distribution System. The study reported that the Public Distribution System suffers from shortage of stocks, fake supply entries in ration cards and diversion of commodities for sale to open market. The study reported that adequate food is available in the country. However, the inequitable access and mismanagement is the main problem for food security. The study concluded that computerization has helped in modernising the Public Distribution System and in improvising the performance in some states.

Kaja P., Gellaboina K.K. (2016), in the study titled 'Looking at Regulatory Mechanism of India's Public Distribution System through Food Security Lens' reported that India's vigilance and implementation of stringent regulations encounters criticism. Though, National Food Security Act 2013 covers 66\% of country's population, the system of public distribution suffers from leakages, higher errors in inclusion of ineligible and exclusion of eligible beneficiaries. The authors in the study, highlighted proactive technology usage by states by adopting Aadhar Seeding (Unique Identification Number) of entire beneficiary database, end-to-end computerization of the entire supply chain and introduction of e-POS(Electronic Point of Sale) machines.

Thangalakshmi T., Suthacini V. (2019) in the study on 'Food Security in India: Issues and Suggestion to Improve the Public Distribution System' reported that Food security in India is unfavourably affected by several biotic and sociopolitical situations. The discipline of human population and land for cultivation, climate change, government policies of public distribution and marketing of food grains and lack of a participatory approach, all are committing to check down the availability of foods. The study suggested that the more active involvement of the panchayats in the PDS can significantly progress access at the village level.

Ozili P., Arun T. (2020), in the study titled 'Spillover of COVID-19: Impact on the Global Economy' reported that the spread of the corona virus has brought the global economy to halt in two ways. Firstly, the spread of the virus encouraged social distancing which led to the shutdown of financial markets, corporate offices, businesses and events. Secondly, the exponential rate at which the virus was spreading and the heightened uncertainty about how bad the situation could get, led to flight to safety in consumption and investment among consumers, investors and international trade partners.

Sergio Correia, Stephan Luck and Emil Verner (2020) in the study titled 'Pandemics Depress the Economy, Public Health Interventions Do Not: Evidence from the 1918 Flu' reported that more exposed areas to pandemic experience a sharp and persistent decline in economic activity. The downturn is driven by both supply and demand-side channels.

\section{Identification of Research Problem}

Adequate research has not been carried out in the State of Goa in the area of Public Distribution System. Further, the outbreak of COVID-19 has further enhanced the significance of Public Distribution System to ensure the supply of essential commodities. The announcement of free ration under Pradhan Mantri Garib Kalyan Anna Yojana also directs to conduct a 
study to understand the perception of stakeholders associated with Public Distribution System.

The present study shall reveal the experiences of beneficiaries in accessing the food grains, supplied under Public Distribution System. Further, limited studies are conducted to understand the problems faced by Fair Price Shops in management of distribution of commodities to beneficiaries. The role of government authorities in conducting inspection activities and ensuring the holistic supply of essential commodities also needs to be explored. On all the above parameters, the present study will prove to be significant and unique.

\section{OBJECTIVE OF THE STUDY}

The main objective of the study is to analyse the performance of Public Distribution System in the State of Goa amidst COVID-19 pandemic. However, the specific objectives of the study are;

- To examine the role of Public Distribution System in ensuring effective supply of essential commodities to beneficiaries in the State of Goa amidst COVID-19 Pandemic.

- To analyze perception of beneficiaries of Public Distribution System and the Fair Price Shop owners towards the functioning of Public Distribution System in Goa during COVID-19 Pandemic.

- To study the measures taken by Department of Civil Supplies, Government of Goa to combat COVID-19 pandemic in the State of Goa.

\section{RESEARCH METHODOLOGY}

In order to study the above stated objectives, the following research methodology has been adopted and executed.

\section{Major area of Study}

The entire study is divided into three major areas. They are:

- Perception of beneficiaries of Public Distribution System

- Perception of Fair Price Shop Owners

- Measures taken by Department of Civil Supplies - Government of Goa

\section{(A) Perception of Beneficiaries of Public Distribution System}

\section{(a) Universe}

The total number of 1328324 beneficiaries of Public Distribution System is considered as the Universe for this part of the study.

\section{b) Sample Size}

For the purpose of the study, the sample size of 87 beneficiaries of Public Distribution System in Goa has been selected and studied.

\section{(B) Perception of Fair Price Shop Owners}

\section{(a) Universe}

The total number of 478 Fair Price Shops operating in the State of Goa is considered as the Universe for this part of the study. 


\section{(b) Sample Size}

For the purpose of studying the perception of Fair Price Shop Owners towards Public Distribution System, 30 Fair Price Shops are selected and studied.

\section{(C) Measures Taken by Department of Civil Supplies - Government of Goa}

Department of Civil Supplies is selected and studied to study the measures taken by Government to combat the COVID-19 pandemic in the State of Goa

\section{Scope of the Study}

The study is limited to the State of Goa. It is also based on beneficiaries' feedback and the responses obtained during the interviews with Fair Price Shop owners. The actions taken by Department of Civil Supplies, Government of Goa to combat COVID-19 are also studied.

\section{Sources of Data}

The required and relevant data for the study is collected through both primary and secondary sources.

\section{Primary Data}

The primary data is collected from 87 beneficiaries of PDS, from the state of Goa. Interview with 30 Fair Price Shop owners were conducted. The data was also obtained from Department of Civil Supplies, Government of Goa.

\section{Secondary Data}

The secondary data has been collected from books, booklets, journals and mainly collected from the various internet resources.

\section{Period of the Study}

The period of study is the period of survey i.e. from $1^{\text {st }}$ April 2020 to $20^{\text {th }}$ May 2020.

\section{Data Analytical Tools}

The collected data has been analyzed by using the following statistical tools;

- Factor Analysis

- Regression Analysis

\section{Hypothesis}

Ho: There is no significant influence of Inadequacy of Quota of Food Grains, Transport, Poor Service, Safety Issues and Lack of Adequate Supervision on Unwillingness of beneficiaries to visit Fair Price Shop in the State of Goa during COVID19 pandemic.

\section{Global Food Crisis during Corona Pandemic}

While the world fights with the coronavirus pandemic, the United Nations food agency warned that a looming hunger pandemic will bring the worst humanitarian crisis since World War II.

According to reports of United Nations food agency, World Food Program Executive Director David Beasley 
remarked that before the onset of the coronavirus pandemic, 821 million people experience chronic hunger while another 135 million people face "crisis levels of hunger". As a result of the coronavirus outbreak and the subsequent economic ramifications, the food agency found an additional 130 million people could be on the brink of starvation by the end of the year. The working poor would be hit the hardest as a result of the decline in tourism and exports, collapse of oil prices and any declines to foreign aid across the globe.

Together, the number of people facing acute food insecurity could nearly double in the current year to 265 million due to the economic fallout of COVID-19, according to the United Nations World Food Programme (WFP).

According to Food and Agriculture Organization of the United Nations, Rome, there are five phases to Integrated Food Security and Humanitarian Phase Classification (IPC); Generally Food Secure, Moderately / Borderline Food Insecure, Acute Food and Livelihood Crisis, Humanitarian Emergency and Famine / Humanitarian Catastrophe.

These phases can be summarized as below;

Generally Food Secure - Usually adequate and stable food access with moderate to low risk of sliding into Phase 3,4 or 5 .

Moderately/Borderline Food Insecure - Borderline adequate food access with recurrent high risk (due to probable hazard events and high vulnerability) of sliding into Phase 3, 4 or 5 .

Acute Food and Livelihood Crisis - Highly stressed and critical lack of food access with high and above usual malnutrition and accelerated depletion of livelihood assets that, if continued, will slide the population into Phase 4 or 5 or likely result in chronic poverty.

Humanitarian Emergency - Severe lack of food access with excess mortality, very high and increasing malnutrition, and irreversible livelihood asset stripping.

Famine / Humanitarian Catastrophe - Extreme social upheaval with complete lack of food access and / or other basic needs where mass starvation, death, and displacement are evident.

According to World Food Programme, COVID-19 is potentially catastrophic for millions who are already hanging by a thread. "Acute food and livelihood crisis" is category three of five UN phases, which means a "critical lack of food access and above usual malnutrition".

\section{India's Approach to Food Management During Corona Pandemic}

Ever since the World Health Organisation designated Coronavirus Disease as pandemic, Government of India under the Ministry of Health and Family Welfare invoked the Epidemic Diseases Act of 1897 to take special measures and prescribe regulations for curtailing the effect of pandemic. The series of measures continued. On the forefront to ensure food security amidst Janta Curfew and subsequent lockdowns, States across India initiated measures to meet the basic need of food for the people. Government of India unveiled a Rs 1.7 lakh-crore fiscal stimulus package to help the poor and migrants tackle the financial difficulties arising from the coronavirus outbreak.

According to the International Labour Organization, at least 90\% of India's workforce is employed in the informal sector, working in roles like security guards, cleaners, rickshaw pullers, streets vendors, garbage collectors and domestic helps. As a counter to COVID-19, India stopped people from travelling to one city from another to avoid community 
transmission. One way of doing this was by ensuring food security.

The unveiling of Rs 1.7 lakh crore economic stimulus plan by India rightly aimed at providing direct cash transfer to poor senior citizens and women and free foodgrain and cooking gas to give relief to millions hit by the lockdown.

The government announced the supply of five kilograms of either rice or wheat to poor households every month for a period of three months under Pradhan Mantri Garib Kalyan Anna Yojana, in addition to the existing five kilograms of wheat/rice under National Food Security Act 2013.

Farmers were given the first instalment of Rs 2,000 under the Kisan Samman Nidhi in the first week of April.

Department of Agriculture, Cooperation and Farmers Welfare took several measures to facilitate the farmers and farming activities at field level during the lock down period.

Procurement of Pulses and Oilseeds on Minimum Support Price (MSP) was initiated in twenty States during Rabi season 2020. A quantity of over 167000 tonnes of Pulses and over 111000 tonnes of Oilseeds were procured by National Agricultural Cooperative Marketing Federation of India Ltd. (NAFED) and Food Corporation of India (FCI).

A separate cell was constituted for monitoring supply and prices of essential goods and fruits and vegetables along with inter-state movement for Northeast region. Agriculture Ministry coordinated with Maharashtra Mandi Board for supply of onion from the production areas of Maharashtra to other States.

Under Pradhan Mantri Garib Kalyan Yojana more than 33 crore poor people were directly given financial assistance of 31,235 crore rupees.

Over 10,000 crore rupees were disbursed to 20.05 crore women Jan Dhan account holders. A total of 1,405 crore rupees were disbursed to about 2.82 crore old-age persons, widows and disabled persons. Under first instalment of PMKISAN, an amount of 16,146 crore rupees is transferred to eight crore farmers.

Around 162 crore rupees have been transferred to over 68,000 establishments as Employees' Provident Fund contribution, benefiting 10.6 lakh employees. A total of 2.17 crore building and construction workers are given financial support amounting to 3,497 crore rupees. Under Pradhan Mantri Garib Kalyan Yojana, free ration of food grains have been distributed to 39.27 crore beneficiaries. In all, 2.66 crore free Ujjwala cylinders have been delivered under Pradhan Mantri Ujjwala Yojana.

In addition, to the above measures, Government of India declared its second stimulus to the tune of Rs.20 lakhs crore package. The package includes free distribution of foodgrain to stranded migrant workers for two months and credit to farmers, totaling Rs.3.10 lakh crore.

\section{Discussion and Analysis}

The population of Goa as per census 2011 stands at 1458545. The scheme of Public Distribution System covers 91.07\% of whole of population of the State of Goa. The total of 13,28,324 citizens are distributed with foodgrains under Public Distribution System on monthly basis.

The Department of Civil Supplies and Consumer Affairs, Government of Goa allocated ration at the following rates for the month of May, 2020 across the State through Fair Price Shops. 
Table 1: Allocation of Ration Quota for the Month of May, 2020

\begin{tabular}{|c|c|c|c|c|}
\hline Commodities & $\begin{array}{l}\text { AAY Ration Pink } \\
\text { Cards }\end{array}$ & PHH Ration Pink Cards & $\begin{array}{c}\text { APL Ration Yellow } \\
\text { Cards }\end{array}$ & $\begin{array}{l}\text { ANP Ration Pink } \\
\text { Cards }\end{array}$ \\
\hline Rice & $\begin{array}{l}35 \mathrm{Kg} / \mathrm{Card} @ \\
\text { Rs.3/Kg }+5 \mathrm{Kg} \text { per } \\
\text { person free of cost } \\
\text { under PM-GKAY }\end{array}$ & $\begin{array}{l}5 \mathrm{Kg} / \text { Beneficiary @ } \\
\text { Rs.3/Kg }+5 \mathrm{Kg} \text { per person } \\
\text { free of cost under PM- } \\
\text { GKAY }\end{array}$ & $\begin{array}{l}13 \text { Kg/Card @ } \\
\text { Rs.12.50/Kg }\end{array}$ & $\begin{array}{l}10 \mathrm{Kg} / \text { Card } \\
\text { Free of cost }\end{array}$ \\
\hline Sugar & $\begin{array}{l}1 \mathrm{Kg} / \mathrm{Card} @ \\
\text { Rss.13.50 / Kg }\end{array}$ & $\begin{array}{l}3 \mathrm{Kg} / \mathrm{Card} \text {, together for } \\
\text { April, May and June, } 2020 \\
\text { @ Rs.13.50/- }\end{array}$ & NA & NA \\
\hline Turdal & $\begin{array}{l}3 \mathrm{Kg} / \text { Card, together } \\
\text { for April, May } 2020 \\
\text { Free of cost under } \\
\text { PM-GKAY }\end{array}$ & $\begin{array}{l}3 \mathrm{Kg} / \text { Card, together for } \\
\text { April, May } 2020 \\
\text { Free of cost under PM- } \\
\text { GKAY }\end{array}$ & $\begin{array}{l}2 \mathrm{Kg} / \mathrm{Card} \text {, together } \\
\text { for April and May } \\
2020 @ \mathrm{Rs} .83 / \mathrm{Kg}\end{array}$ & $\begin{array}{l}2 \mathrm{Kg} / \mathrm{Card} \\
\text { together for April } \\
\text { and May } 2020 @ \\
\text { Rs.83/Kg }\end{array}$ \\
\hline Wheat & NA & NA & $\begin{array}{l}4 \mathrm{Kg} / \text { card @ } \\
\text { Rs.10/kg }\end{array}$ & NA \\
\hline
\end{tabular}

Source: Department of Civil Supplies and Consumer Affairs, Government of Goa

The above table no. 4 shows the eligible quantity of ration quota for the month of May, 2020 along with prices applicable to various categories of ration cards. Rice is distributed at Rs.3 per kg for AAY and PHH ration card holders. The APL card holders are charged Rs.12.50 per kg whereas the Annapurna (ANP) card holders are given $10 \mathrm{~kg}$ of free food grains. In addition to the regular monthly ration quota of rice of $35 \mathrm{~kg}$ per card on AAY ration card, five kilo grams of rice is distributed free of cost under Pradhan Mantri - Garib Kalyan Ann Yojana (PM-GKAY). The PHH ration card holders are also offered five kilo grams of rice free of cost under PM-GKAY. Further, three Kilo grams of Turdal is distributed free of cost to AAY and PHH ration card holders under PM-GKAY. The APL and ANP ration card holders are also distributed with two kilograms of Turdal at Rs.83 per kg.

\section{Analysis of perception of Beneficiaries towards Public Distribution System}

The data from beneficiaries on various difficulties faced while accessing food grains at the Fair Price Shops is analyzed by carrying out factor analysis. To test the reliability of the data, the following value is reported;

Table 2: Reliability Statistics

\begin{tabular}{|c|c|}
\hline Cronbach's Alpha & No. of Items \\
\hline .923 & 18 \\
\hline \multicolumn{2}{|c|}{ Source: Computed From Primary Data }
\end{tabular}

The above Table No.2 shows Cronbach's Alpha for Reliability Statistics for 18 variables on difficulties faced by PDS Beneficiaries on Public Distribution System as 0.923. The minimum Cronbach's Alpha value accepted for internal consistency of the data is 0.70 . The Cronbach's value of 0.923 for 18 variables is considered strong to judge the internal consistency of the data.

Further, the adequacy of data for carrying out factor analysis is determined through Kaiser-Meyer-Olkin (KMO) Test. The test measures the sampling adequacy for each variable in the model. KMO statistic is a measure of the proportion of variance among the variables.

Table 3: KMO and Bartlett's Test

\begin{tabular}{|l|l|c|}
\hline \multicolumn{2}{|l|}{ Kaiser-Meyer-Olkin Measure of Sampling Adequacy. } & .860 \\
\hline \multirow{3}{*}{ Bartlett's Test of Sphericity } & Approx. Chi-Square & 802.995 \\
\cline { 2 - 3 } & Df & 136 \\
\cline { 2 - 3 } & Sig. & .000 \\
\hline
\end{tabular}

Source: Computed From Primary Data 
KMO values between 0.8 and 1 indicate that the data is adequate for carrying out factor analysis. The KMO value of 0.860 reported in Table No.3 signifies that data is adequate.

Table 4: Rotated Factor Matrix

\begin{tabular}{|c|c|c|c|}
\hline \multirow[b]{2}{*}{ Problems Faced by Beneficiaries } & \multicolumn{3}{|c|}{ Main Factors } \\
\hline & $\begin{array}{c}\text { Inadequacy of } \\
\text { Quota of Food } \\
\text { Grains } \\
\end{array}$ & $\begin{array}{c}\text { Transport, Poor } \\
\text { Service and Safety } \\
\text { Issues }\end{array}$ & $\begin{array}{c}\text { Lack of } \\
\text { Adequate } \\
\text { Supervision } \\
\end{array}$ \\
\hline Inadequate Foodgrains & \begin{tabular}{|l|}
.869 \\
\end{tabular} & & \\
\hline Food Insecurity & .817 & & \\
\hline Inferior quality & & .517 & \\
\hline Inaccurate weightment & & .668 & \\
\hline No Cleanliness and hygiene & & .702 & \\
\hline FPS owner is not courteous & & .582 & \\
\hline Difficulty to travel to the Fair Price Shop & & .748 & \\
\hline Quota preceeding month is still awaited & & .627 & \\
\hline No adequate safety to visit the Fair Price Shop & & .620 & \\
\hline Inconvenient Working Hours & & & .732 \\
\hline No up-to-date Provision of information & & & .622 \\
\hline Poor regulation of Timing of Fair Price Shop & & & .769 \\
\hline Long wait at Fair Price Shop & & & .692 \\
\hline Closed Fair Price Shop on arrival of Beneficiary & & & .831 \\
\hline $\begin{array}{l}\text { Non allotment of entitled Actual Quota of food } \\
\text { grains }\end{array}$ & . & & 523 \\
\hline Indifferent attitude of the Fair Price Shop dealer & & & .554 \\
\hline No social distancing is maintained & & & .610 \\
\hline Eigen Values & 4.217 & 4.044 & 2.050 \\
\hline Variance & 24.806 & 23.787 & 12.056 \\
\hline Cumulative Variance & 24.806 & 48.593 & 60.649 \\
\hline
\end{tabular}

\section{Source: Computed from Primary Data}

The result of Varimax with Kaiser Normalization has given three factors. The above factors have been named as, Inadequacy of Quota of Food Grains, Transport, Poor Service and Safety Issues and Lack of Adequate Supervision.

The first factor is named as Inadequacy of Quota of Food Grains includes the variables such as inadequate foodgrains and food insecurity.

The second group of factor has been named as Transport, Poor Service and Safety Issues. This factor further includes variables such as inferior quality, inaccurate weighment, no cleanliness and hygiene, Fair Price Shop owner is not courteous, difficulty to travel to the Fair Price Shop, quota preceding month is still awaited and no adequate safety to visit the Fair Price Shop.

The third group has been given name as Lack of adequate supervision. Lack of adequate supervision includes variables such as inconvenient working hours, no up-to-date provision of information, poor regulation of timing of Fair Price Shop, long wait at Fair Price Shop, closed Fair Price Shop on arrival of beneficiary, non allotment of entitled actual quota of food grains, indifferent attitude of the Fair Price Shop dealer and no social distancing is maintained.

The above Table No. 4 explains the total variance explained for unwillingness of the beneficiaries to visit fair price in the State of Goa with 19 variables by showing a $60.649 \%$ of total variance with 3 Eigen values i.e. 4.217, 4.044 and 2.050. All these Eigen values are greater than one. This depicts the existence of three major factors. Individually these factors are 
having variances of $24.806,23.787$ and 12.056 . Further, according to the variables under each factor; these prominent factors are used for additional analysis.

\section{Regression Analysis}

After carrying out exploratory factor analysis on 17 variables, 3 prominent factors were extracted. These three factors are Inadequacy of Quota of Food Grains, Transport, Poor Service and Safety Issues and Lack of Adequate Supervision. These three factors are further regressed to find the influence on unwillingness of beneficiaries to visit Fair Price Shop.

\begin{tabular}{|c|c|c|c|c|}
\hline Model & R & R Square & Adjusted R Square & Std. Error of the Estimate \\
\hline & $.737^{\text {a }}$ & .543 & .527 & .698 \\
\hline
\end{tabular}

\section{Source: Computed From Primary Data}

The model summary in Table No.5 depicts adjusted R-square at 0.527 . This shows that independent variables and the dependent variable of unwillingness to visit Fair Price Shop has a strong relationship. The regression model explains $52.7 \%$ influence of independent variables on dependent variable.

Table 6: ANOVA

\begin{tabular}{l|l|c|c|c|c|c|}
\hline Model & Sum of Squares & DF & Mean Square & F & Sig. \\
\hline & 48.127 & 3 & 16.042 & 32.882 & $.000^{\mathrm{b}}$ \\
\hline & 40.493 & 83 & .488 & & \\
\cline { 2 - 4 } & 88.621 & 86 & & & \\
\hline Residual & Total & & & \\
\hline a. Dependent Variable: Unwillingness to visit the Fair Price Shop \\
Predictors: (Constant), Inadequacy of Quota of Food Grains, Transport, Poor Service and Safety Issues and Lack \\
of Adequate Supervision.
\end{tabular}

\section{Source: Computed from Primary Data}

The Table No. 6 shows that the above multiple regression analysis model is significant at $5 \%$ level of significance.

Table 7: Result of Coefficients for Unwillingness of Beneficiaries to Visit the Fair Price Shop

\begin{tabular}{|l|c|c|c|c|c|}
\hline \multirow{2}{*}{\multicolumn{1}{c|}{ Model }} & \multicolumn{2}{c|}{$\begin{array}{c}\text { Unstandardized } \\
\text { Coefficients }\end{array}$} & $\begin{array}{c}\text { Standardized } \\
\text { Coefficients }\end{array}$ & & \\
\cline { 2 - 6 } & B & Std. Error & Beta & T & Sig. \\
\hline Constant) & 3.310 & .075 & & 44.206 & .000 \\
\hline Inadequacy of Quota of Food Grains & .388 & .075 & .382 & 5.147 & .000 \\
\hline Transport, Poor Service and Safety Issues & .625 & .075 & .615 & 8.294 & .000 \\
\hline Lack of Adequate Supervision & .138 & .075 & .136 & 1.836 & .070 \\
\hline a. Dependent Variable: Unwillingness to visit the Fair Price Shop & & & \\
\hline
\end{tabular}

\section{Source: Computed from Primary Data}

The multiple regression equation is as follows;

$y=\beta_{0}+\beta_{1} X_{1}+\beta_{2} X_{2}+\ldots .+\varepsilon$ (Douglas Montgomery, Peck, \& Vinning, 2012).

Where;

$\mathrm{Y}=$ dependent variable

$\beta_{1,} \beta_{2 \ldots} \ldots n=$ Coefficients of the variables 
$\mathrm{X}_{1,} \mathrm{X}_{2} \ldots \mathrm{X}_{\mathrm{n}}=$ Known Variables

The dependent and independent variables are as follows;

Dependent Variable: Unwillingness to visit the Fair Price Shop

Independent Variables:

- Inadequacy of Quota of Food Grains $\left(\mathrm{X}_{1}\right)$

- $\quad$ Transport, Poor Service and Safety Issues $\left(\mathrm{X}_{2}\right)$

- $\quad$ Lack of Adequate Supervision $\left(\mathrm{X}_{3}\right)$

Therefore, the regression equation from table-7 is;

$Y=3.310+0.388 X_{1}+0.625 X_{2}$

The above estimated coefficients represents that the factors identified through exploratory factor analysis on unwillingness of beneficiaries of PDS to visit Fair Price Shop in the State of Goa are having positive influence. The coefficient values of $X_{1}$ and $X_{2}$ are significant at $5 \%$ level of significance. The coefficient value of $X_{3}$ is insignificant. Since the p-values for $\mathrm{X}_{1}$ and $\mathrm{X}_{2}$ are less than 0.05 at $5 \%$ level of significance the null hypothesis Ho is rejected in respect of Inadequacy of Quota of Food Grains and Transport, Poor Service and Safety Issues.

From the above analysis it is evident that food quota, transport problem of beneficiaries, poor service at Fair Price Shop and safety issues has to be looked into to further improve the willingness among beneficiaries to visit Fair Price Shop and thereby increase satisfaction towards Public Distribution System in the State of Goa. Unless the beneficiaries are satisfied with the pubic distribution system, the intended goals of Public Distribution System will not be achieved. In the present unprecedented times of COVID-19, the safety issues are of prime significance as any neglect in this aspect could be detrimental. It was pertinent to observe from the responses of the beneficiaries that inspite of all problems and unwillingness revealed towards Public Distribution System, the beneficiaries continue to visit Fair Price Shop for their needs of food security.

\section{Analysis of Perception of Fair Price Shop Owners}

Fair Price Shops act as a main link between the government authorities and the beneficiaries of Public Distribution System. Fair Price Shops lifts quota of food grains allotted to them from taluka level godowns between $22^{\text {nd }}$ to $30^{\text {th }}$ of each month and distributes the same in the next month from $1^{\text {st }}$ to $21^{\text {st }}$ at their designated places. The outbreak of COVID-19 has resulted into several challenges to Fair Price Shop owners in addition to their regular concerns;

\section{Social Distancing}

The Fair Price Shop owners revealed that the announcement of additional stock by central government under Pradhan Mantri Garib Kalyan Anna Yojana to ration card holders under National Food Security Act 2013 attracted beneficiaries to Fair Price Shop in a large group. The number of beneficiaries visited Fair Price Shop together in the beginning of the April month. The Fair Price Shop owners opined that handling initial crowd was difficult as the beneficiaries had to be convinced about the status of the stock at the Fair Price Shops. The Fair Price Shop owners further added that after the distribution of ration for initial days, the beneficiaries accepted the norm of social distancing is for their own safety. Wearing of masks was stressed 
upon and a hand sanitizer was also made available at the Fair Price Shop.

\section{Transport}

One of the major issues raised by Fair Price Shop owners is that of insufficient remittances being paid towards transport expenses. The Fair Price Shop owners were dissatisfied over promises made by government authorities that the transport reimbursement is not sufficient to meet their expenses.

\section{Labour Charges}

The expenses of loading at taluka level godowns and unloading at Fair Price Shop adds to the woes of the Fair Price Shop owners.

\section{Extra Working Hours}

The Fair Price Shop owners further revealed their discontentment towards extension of working hours and cancellation of weekly off from the business. It has further reduced their family time and peace of mind.

\section{Low Commission on Regular Ration}

The Fair Price Shop owners consider operating a Fair Price Shop as economically unviable. The Fair Price Shop owners rely on their alternative occupations to meet the need of their family. They further added that the income from Fair Price Shop gives them a rare opportunity to accumulate savings for future.

\section{No Reimbursement of Expenses for Free Quota of Ration}

With anguish and displeasure in the eyes, the Fair Price Shop owners added that no commission or transport allowance is enjoyed by them for distribution of free quota for three months ending $30^{\text {th }}$ June 2020 due to COVID-19 pandemic. However, the Fair Price Shop owners revealed that the government has only promised that in future the dues shall be reimbursed to them.

\section{Place Constraint}

One of the constraints encountered by Fair Price Shop owners included the poor storage facility for pulses (dal). The Fair Price Shop owners opined that this commodity soon gets spoiled. The additional stock to be lifted due to the announcement of free ration under Pradhan Mantri Garib Kalyan Ann Yojana also created storage problems for the Fair Price Shop owners.

\section{Lifting of Quota from Godown}

Fair Price Shop owners further added the procedures observed while lifting quota from taluka level godowns to the Fair Price Shop to be time consuming. The procedure involves generating a challan for onward payment at the designated bank branch of the government authorities. Further, on the payment in the bank account, the receipt is issued to the Fair Price Shop owner by the bank officials. The Fair Price Shop owner later presents the receipt at the taluka level Civil Supplies Office which issues permit to lift commodities from the godown. It is only upon the valid permit issued by Civil Supplies Office, the Fair Price Shop owners can shift stock from taluka level godown to their respective Fair Price Shop.

\section{Difficulty in Informing Beneficiaries to Lift Quota}

The Fair Price Shop owners also admitted that they face difficulty in informing the beneficiaries about the availability of the commodities at the Fair Price Shop to be lifted by the respective beneficiaries each month. 


\section{Complaints from APL Card Holders}

It was further said that there were instances where in the Fair Price Shop owners' had to listen to the complaints from the Above Poverty Line (APL) Card holders that no schemes of free quota is being designed for their needs.

Fair Price Shop owners revealed that inspite of all difficulties the ration is being made available at right time, at right place, in right quantity and at right price to the ration card holders.

\section{Measures Taken by Department of Civil Supplies - Government of Goa}

The Department of Civil Supplies and Consumer Affairs, Government of Goais a regulatory Department and implements various statutory provisions as contained in the Essential Commodities Act 1955 and the rules made there under regulating procurement and distribution of essential commodities under Public Distribution System. This is one of the departments which have close contact with the general public. The Department is committed to protect and guard the interest of the consumers in Goa. The department took various actions to combat COVID-19 pandemic in Goa. Some of these actions are as under;

- As per the notification of Government of India the Department of Civil Supplies and Consumer Affairs, re-published the Notification regulating the prices of masks and sanitizers which were included in essential commodities. The department also issued press notes for the awareness for the general public.

- To maintain availability and supply of diesel and petrol for essential vehicles the Department also issued Order regarding operations of Petrol Pumps and also delivery of LPG Cylinders to the consumers by LPG Companies.

- Frequent meetings with Wholesale Suppliers and HODs of the other line Departments associated with the Civil Supplies and Consumer Affairs were conducted whenever required to review the status and streamline the supply chain of essential commodities and maintain availability of essential foods in the market for general public.

- The Department made appeal to Cooperative Stores, Wholesalers, Stockiest of essential commodities and the entire related supply chain covering transportation, distribution of essential commodities etc. to keep operational throughout Goa.

- The Department issued Circular on Advisory to be adhered by the Fair Price Shop owners to contain the spread of COVID-19 pandemic. The Department exempted the beneficiaries from biometric authentication on e-POS device for lifting of their entitled quota and Fair Price Shop owners were asked to authenticate regarding distribution of foodgrains quota.

- The Fair Price Shop owners who delayed lifting quota were issued show cause notices by the Department of Civil Supplies. The Department of Civil Supplies informed that as many as 194 Fair Price Shop owners were issued show cause notices across the State.

- The Director of Civil Supplies intervened with other States' Authorities to clear and smoothen the movement of vehicles carrying essential commodities, which were stopped at check posts and not allowed to cross the borders, thereby streamlining the supply chain of essential commodities in the State.

- To overcome the complaints of hoarding, black marketing and ensure availability of essential commodities to the general public in the State, the Department formed a Special Taluka-wise teams comprising of Inspectors of Legal 
Metrology, Inspectors of Commercial Taxes and Inspectors of Civil Supplies to physically open and verify the stock information from the godown of suppliers and wholesaler and were also authorized to action against the violators. These teams were provided with the hired vehicles for conducting inspections. The Department of Civil Supplies further informed that the department faces severe constraints of vehicles while conducting inspection of Fair Price Shop. Inspection is conducted of every Fair Price Shop atleast once in three months.

- The Department also started Grocery on Wheels to ensure the delivery of essential commodities to the Industrial Estate Workers' Complexes where the grocery shops are far away.

- Department also indented and procured 427.5 MTS of Dal (Tur Dal) under Pradhan Mantri Garib Kalyan Anna Yojana for National Food Security Act (NFSA) beneficiaries for its free distribution. The Department also indented additional 304 MTS of Dal for providing to Non-NFSA beneficiaries for a period of 3 months.

- Department ensured the delivery and distribution of foodgrains allotted under Pradhan Mantri Garib Kalyan Anna Yojana to eligible NFSA beneficiaries through Fair Price Shops in the State.

- Department also procured sugar for distribution among AAY beneficiaries.

- The Director himself visited various shop places/shelter homes to inspect the status of availability of essential commodities to the general public.

- All the staff including staff of sub-offices of the department is actively involved in combating COVID-19 and is attending their offices regularly by following guidelines.

- In an effort to create more awareness, the staff of the department voluntarily made short movie involving their own kids giving the message of NO MASK, NO RATION and NO MASK, NO FUEL.

\section{CONCLUSIONS AND SUGGESTIONS}

The godowns of Food Corporation of India, Government of India has been overflowing with food grains. The decision to provide extra foodgrains over and above what ration card holders are entitled to get at present under the National Food Security Act (NFSA) was aptly required in these crucial times to ensure supply of essential commodities to people in the economy. Presently, the total stock is 564 lakh tonnes, of which rice accounts for 284 lakh tonnes and wheat, 280 lakh tonnes. As per the norms fixed in 2015, the buffer stock, as maintained on April 1, was around 210 lakh tonnes which changes on the first day of July, October and January. The present stock position is almost triple the requirement of buffer stock.

The measures taken by the Government of India to fight corona pandemic are in the interest of the people and the economy at large. However, the larger significance remains on the effective implementation of these packages for the benefit of the deserving people.

The State of Goa has been the beneficiary of Public Distribution System. The outbreak of COVID-19 has further increased the significance of government controlled Public Distribution System to ensure the supply of essential commodities to the eligible beneficiaries. Some of the areas of concern that has to be looked into include economic viability of Fair Price Shops and dissatisfaction of beneficiaries towards Public Distribution System. The inspection activities need to continue in the stringent possible manner to uplift the rights of beneficiaries at all times. The Department of Civil Supplies has been 
successful in ensuring the supply of essential commodities through Fair Price Shops in these unparalleled times, however, the concerns of beneficiaries and Fair Price Shop owners, both the crucial stakeholders of Public Distribution System, have to be resolved for upholding the objectives with which the entire exercise had been implemented.

\section{REFERENCES}

1. D. Amrutha, D.Rathi (2015), Role and Effectiveness of Public Distribution System in India, https://ssrn.com/abstract=3039010. (Retrieved on $8^{\text {th }}$ April 2020)

2. https://economictimes.indiatimes.com/news/economy/policy/govt - to - provide - 5 - $k g-$ grains $-1-k g$ - pulses - for - free over - next- 3 - months-fm. (Retrieved on $9^{\text {th }}$ April 2020)

3. https://foreignpolicy.com/2020/04/14/how-to-stop-food-crisis-coronavirus-economy-trade/. (Retrieved on $16^{\text {th }}$ April 2020)

4. https://www.aljazeera.com/news/2020/04/global-hunger-double-due-coronavirus-pandemic-200421135911446.html. (Retrieved on $28^{\text {th }}$ April 2020)

5. https://www.bbc.com/news/world-asia-india-52002734. (Retrieved on $8^{\text {th }}$ April 2020)

6. https://www.bbc.com/news/world-asia-india-52360757. (Retrieved on $28^{\text {th }}$ April 2020)

7. https://www.bbc.com/news/world-asia-india-52047263. (Retrieved on $8^{\text {th }}$ April 2020)

8. https://www.bbc.com/news/world-asia-india-52176564. (Retrieved on 14 $4^{\text {th }}$ April 2020)

9. https://www.bloombergquint.com/coronavirus-outbreak/centre-releases-rs-17287-crore-as-states-seeks-funds-to-fight-covid19. (Retrieved on $28^{\text {th }}$ April 2020)

10. https://www.deccanherald.com/opinion/panorama/india-has-enough-food-stocks-to-tide-over-coronavirus-crisis-815502.html. (Retrieved on $8^{\text {th }}$ April 2020)

11. http://www.fao.org/3/i0275e/i0275e.pdf. (Retrieved on 29 ${ }^{\text {th }}$ April 2020)

12. https://www.india.gov.in/news_lists?a932265213. (Retrieved on $29^{\text {th }}$ April 2020)

13. https://www.irishtimes.com/news/world/asia-pacific/india-s-poorest-face-critical-food-shortages-during-covid-19-lockdown1.4219279. (Retrieved on $8^{\text {th }}$ April 2020)

14. https://www.nbcnews.com/news/world/u-n-warns-hunger-pandemic-amid-threats-coronavirus-economic-downturn-n1189326. (Retrieved on $28^{\text {th }}$ April 2020)

15. https://www.ndtv.com/business/coronavirus-covid-19-crisis-finance-minister-nirmala-sitharaman-5-big-announcements-tofight-corona-2201057. (Retrieved on $5^{\text {th }}$ April 2020)

16. https://www.ndtv.com/india-news/coronavirus-saarc-nations-roll-out-stimulus-packages-to-tackle-covid-19-economic-fallout2218473 (Retrieved on $29^{\text {th }}$ April 2020)

17. https://www.reuters.com/article/us-health-coronavirus-food-explainer/explainer-how-the-coronavirus-crisis-is-affecting-foodsupply-idUSKBN21LOD2. (Retrieved on $8^{\text {th }}$ April 2020)

18. https://www.thehindu.com/news/international/how-the-coronavirus-crisis-is-affecting-food-supply/article31244018.ece. (Retrieved on 8h $^{\text {th }}$ April 2020)

19. https://www.thehindubusinessline.com/economy/agri-business/amidst-the-covid-19-pandemic-indias-food-security-atwto/article31234049.ece. (Retrieved on $9^{\text {th }}$ April 2020) 
20. https://www.thejakartapost.com/news/2020/04/20/coronavirus-threatens-to-trigger-new-round-of-global-food-crisis-chinaofficial.html. (Retrieved on $29^{\text {th }}$ April 2020)

21. https://www.wsj.com/articles/india-to-spend-22-5-billion-to-help-poor-survive-coronavirus-shutdown-11585223446. (Retrieved on $28^{\text {th }}$ April 2020)

22. IPC Global Partners (2008), Integrated Food Security Phase Classification Technical Manual, Version 1.1 Food and Agriculture Organization of the United Nations, Rome. (Retrieved on $8^{\text {th }}$ April 2020)

23. Padmaja Kaja, Kiran Kumar Gellaboina (2016), Looking at Regulatory Mechanism of India's Public Distribution System through Food Security Lens, OIDA International Journal of Sustainable Development, Onturio Internation Develoment Agency, Canada, ISSN 1923-6654, pp.11-18. (Retrieved on $8^{\text {th }}$ April 2020)

24. Peterson Ozili, Thankom Arun (2020), Spillover of COVID-19: Impact on the Global Economy, https://ssrn.com/abstract $=3562570$. (Retrieved on $8^{\text {th }}$ April 2020)

25. Nirankar Srivastav and Amresh Dubey (2001), How and Why the access to Public Distribution System does not enhance the food security among the people of North East India - An Inter State Analysis, Globalisation and Development Dilemma, pp.295307. (Retrieved on $8^{\text {th }}$ April 2020)

26. Sergio Correia, Stephan Luck, and Emil Verner (2020), Pandemics Depress the Economy, Public Health Interventions Do Not: Evidence from the 1918 Flu, https://ssrn.com/abstract=3561560. (Retrieved on $8^{\text {th }}$ April 2020)

27. T. Thangalakshmi, V.Suthasini (2019), Food Security in India: Issues and Suggestion to Improve the Public Distribution System, International Journal of Economics, Volume 7, Issue-4, September 2019, pp.36-40. (Retrieved on $8^{\text {th }}$ April 2020)

28. Chakraborty, Samarpan, and Debabrata Basu. "Homestead Gardening: An Emerging Venture Towards Achieving Food Security \& Nutritional Security-A Study of Selected Areas of West Bengal." International Journal of Applied and Natural Sciences (IJANS) 7.1 (2018): 49-62.

29. TRIPATHI, PRIYANSHU, and NIKITA WADHAWAN. "IMPACT OF MGNREGA TO ACHIEVE FOOD SECURITY AMONG RURAL HOUSEHOLD. " International Journal of Applied and Natural Sciences (IJANS) 6.4 (2017):145-148

30. IFEANYIEZE, FO, and I. OKEME. "ENTREPRENEURIAL COMPETENCY IMPROVEMENT NEEDS OF WOMEN IN AGRICULTURE IN PROCESSING AFRICAN YAM BEAN SEEDS FOR FOOD SECURITY IN NORTH CENTRAL STATES OF NIGERIA." IMPACT: International Journal of Research in Applied, Natural and Social Sciences (IMPACT: IJRANSS) 2.6 (2014):13-22

31. Lt, TJPRC Pvt. "AN ANALYSIS OF THE EFFECT OF LIVELIHOOD DIVERSIFICATION ON THE FOOD SECURITY STATUS OF THE RURAL FARMING HOUSEHOLDS IN UDI LGA OF ENUGU STATE." International Journal of Agricultural Science and Research (IJASR) 7.6 (2017):389-398

32. KANG, ANAHAT, JS KANG, and JAGROOP KAUR. "HERBICIDES ARE ESCALATING SEVERE PUBLIC HEALTH PROBLEMS BUT UNAVOIDABLE FOR FOOD SECURITY." International Journal of Medicine and Pharmaceutical Science (IJMPS) 6.4 (2016):1-12

33. Farooqui, Noria, and Naushadul Mullick. "Domestic and International Food Security: Issues and Challenges." International Journal of Food Science and Technology (IJFST) 63 (2016): 1-4.

34. Chadha, N. E. E. R. U. "Food security in India: issues and challenges." International Journal of Humanities, Arts, Medicine and Sciences (BEST: IJHAMS) 4.1 (2016): 79-86.

35. KASSENOV, MURATBEK R. "SUSTAINABLE DEVELOPMENT OF AGRO-FOOD MARKET IN TERMS OF PROVIDING 
NATIONAL FOOD SECURITY: EXPERIENCE OF SOME COUNTRIES." International Journal of Economics, Commerce and Research (IJECR) 3.4 (2013):37-42 